\title{
The Feldstein-Horioka Hypothesis in Countries with Varied Levels of Economic Development
}

\author{
Piotr Misztal
}

ABSTRACT

\begin{abstract}
This article aims to analyse the Feldstein-Horioka hypothesis, which suggests a strong correlation between investments and savings in advanced economies. Additionally, the analysis of the Feldstein-Horioka hypothesis was expanded to include emerging markets and developing economies in order to provide a thorough analysis of this issue. 'The paper utilises a research method based on bibliographic studies in macroeconomics and international finances as well as econometric methods (the vector autoregressive model - VAR). All statistical data used in the paper are taken from the statistical database of the International Monetary Fund (World Economic Outlook Database).
\end{abstract}

KEY WORDS: $\quad$ savings, investments, VAR model

JEL Classification: E21, E22

${ }^{1}$ Technical University of Radom, Poland

\section{Introduction}

Throughout the last three decades, various empirical studies were conducted to explain and solve the Feldstein-Horioka hypothesis. The Feldstein-Horioka puzzle (F-H) refers to a landmark paper by Feldstein and Horioka (1980), in which they proved that investments and savings are highly correlated in advanced economies, which also proves low international capital mobility. The results of Feldstein's and Horioka's research (1980) showed that the so-called saving retention coefficient, which measured the level of capital mobility in 21 member states of the Organisation for Economic Co-operation and Development (OECD), was between 0.871 and 0.909 , which proved a relatively low level of capital mobility in these countries. These results meant

Corespondence concerning to this article should be addressed to: misztal@tkdami.net that almost $90 \%$ of savings in OECD member states stay in their countries of origin and are used to finance domestic investments (Strzała, 2005). These controversial results also sparked numerous debates in domestic and foreign literature on economics (Sinn, 1992; Baxter, Crucini 1993; Deckle, 1996; Jansen, 1996; Caporale, Panopoulou, Pittis, 2005; Mastroyiannis, 2007; Bhaskara, Tamazian, Kumar 2010; Ketenci, 2010). Several empirical studies provided arguments to back Feldstein's and Horioka's theses. Owing to this, the results of Feldstein's and Horioka's studies (1980), that are at variance with economic theory, have been called "the mother of all puzzles" (Obstfeld and Rogoff, 2000).

\section{The Ccorrelation Between Domes- tic Savings and Investments in Light of the Theory}

The starting point for the explanation of the relationship between domestic savings and investments is pro- 
vided by the well-known formula for national income given below (Miller 1988):

$$
Y=C+I+G+(X-M)
$$

where: $Y$ - national income; $C$ - private consumption; $I$ - investment expenditure; $G$ - government expenditure; $X$ - export of goods and services; $M$ - import of goods and services.

If we omit the income balance and the government expenditure balance, the current account can be described using the following formula:

$$
C A=(X-M) \quad(2) \text {. }
$$

If a given country exports less than it imports, a deficit appears on the current account and has to be financed by foreign loans. This is why a country with a current account deficit has to increase their net foreign debt by the amount of their current account deficit. Thus, a country with a current account deficit "imports current consumption and/or investments" (if investment goods are imported) and "exports future consumption and/or investment expenditures".

In reference to formula (1) for the national income, domestic savings in an open economy can be expressed as:

$$
S=Y-C-G+C A
$$

where: $S$ - savings.

Alternatively, the formula above can be expressed as:

$$
S=I+C A
$$

where: $I$ - investments, which in turn can be expressed as:

$$
I=Y-C-G
$$

Thus, the current account balance can be described by the following formula:

$$
C A=S-I-(G+R-T)
$$

where: $R$ - governmental transfers; $T$ - taxes.

If we assume in this situation - according to FeldsteinHorioka - that savings and investments are highly correlated, despite relatively high international capital mobility, then the high level of correlation between domestic savings and investments has to mean parallel changes in the budget deficit and current account deficit, which can ultimately be presented by the following formula (Francesca, Stefano 2010):

$$
C A=S-I+B \quad(7)
$$

where: $B$ - state budget balance.

On the other hand, when there is no correlation between savings and investments, a change in budget deficit is fully balanced by the changes in savings, which does not increase the consumption expenditures nor current account deficit. Such situation is called the Ricardian equivalence (Fidrmuc 2003; Mukhtar, Zakaria, Ahmed 2007; Marinheiro 2008).

\section{The Feldstein-Horioka Hypothesis in Light of Empirical Analyses}

The research hypothesis showing the existence of longterm relationships between investments and savings in numerous developed economies (Feldstein-Horioka hypothesis) is considered one of the six main empirical puzzles in modern macroeconomics (Obstfeld and Rogoff, 2000). In the age of progressing liberalisation processes in the international flow of goods, services and factors of production, a free flow of capital enables the effective allocation of capital, regardless of existing state borders. Thus, the size of investment (I) in any open economy should not be limited by the size of domestic savings (S) (Francesca, Stefano, 2010).

Di Iorio and Fachin (2007) used bootstrap methods to study the Feldstein-Horioka hypothesis in 12 European Union (EU) members between 1960 and 2002. The results of this study have shown that the saving retention coefficient for each of these countries was between 0.59 and 1.03 .

On the other hand, Christopuolos (2007) used the least squares method to verify the Feldstein-Horioka hypothesis in 13 OECD members between 1885 and 1992. His results have shown that the average saving retention coefficient was approximately 0.5 throughout the whole time he analysed. However, in case of partial samples, i.e. the periods of 1921-1992 and 1950-1992, the estimated value was actually closer to 0.79 and 0.90 , respectively.

Meanwhile, Murthy (2007) used cointegration techniques to analyse the Feldstein-Horioka hypothesis in fourteen Latin American countries and four Caribbe- 
an countries between 1960 and 2002. His results suggested a rather low correlation between savings and investments, which showed that the Feldstein-Horioka hypothesis does not exist in practice.

Arginon and Roldan (1994) also studied the relationship between savings and investments in EU members between 1960 and 1988 and found a unidirectional causality between these variables. It appeared that the savings were a significant determinant for investments.

Apergis and Tsoulfidis, on the other hand, used an autoregressive distributed lag model (ARDL) to analyse the cointegration of savings and investments in 14 EU countries. They showed that savings and invesments are cointegrated, and savings cause investments in Granger's sense.

Moreover, Tsoukis and Alyousha (2002) conducted a Granger's causality analysis between gross savings and gross investments in seven highly advanced economies (Australia, Canada, Germany, Japan, the Netherlands, Great Britain and the US), starting from 1945. The results of their study only uncovered a cointegration between savings and investments in Australia and Great Britain, and showed that savings were a cause for investment in Granger's sense in both countries.

Nofowara, Owoye, Huart (2011) analysed the relationship between savings and investments in eight highly economically developed EU countries. To do this, they used the autoregressive distributed lag model (ARDL), a vector error correction model (ECM) and a vector autoregressive model (VAR). The authors have found evidence of cointegration between savings and investments in six of those countries. Moreover, the results have shown that savings are a significant determinant for investment in the Netherlands and Great Britain, a reverse causality in Denmark, Germany and Luxembourg, a bidirectional causality in Belgium, and no relationship between savings and investments in France and Italy.

\section{An Analysis of the Feldsteing-Horiok Hypothesis in Advanced Economies, Emerging Markets and Developing Economies}

In order to analyse the relationship between the amounts of investments and savings in advanced economies, as well as in emerging markets and developing economies, this article uses an econometric model proposed by Feldstein and Horioka (1980), expressed in the formula below:

$\left(\frac{I}{G D P}\right)_{t}=\alpha+\beta\left(\frac{S}{G D P}\right)_{t}+U_{t}$

where: $I$ - investments; $S$ - savings; GDP - Gross Domestic Product; $a$ - the absolute term of the formula; $\beta$ - investments' sensitivity to savings increase (savings retention coefficient); the $\beta$ coefficient nearing 0 shows perfect international capital mobility, while $\beta$ nearing 1 shows the lack of international capital mobility; $U$ random parameter; $t$ - analysis duration.

All of the above time series had an annual frequency and included the period between 1980 and 2010. The analysis assumed one full period of delay between the explanatory variables and the explained variable (one year). The delays were chosen according to the results of the information criteria of the Akaike, Schwartz-Bayesian and Hannan-Quinn model. According to these criteria, a model with a single delay had the largest information capacity. The final changes to the indexes used in this model were as shown in the figure below (Fig. 1).

Based on the data above, the correlation coefficient between the rates of investments and savings in advanced economies between 1980 and 2010 was 0.94 , which shows a significant and positive linear relationship between these variables.

However, the calculated correlation coefficient between the rates of investments and savings in emerging markets and developing economies between 1980 and 2010 was 0.78 , which also means a relatively high positive linear relationship between domestic investments and savings, although it is slightly lower than in advanced economies.

Before the model can be estimated, the stationarity of the analysed time series had to be determined. An augmented Dickey-Fuller test was used for this purpose. The ADF test results for advanced economies showed stationarity only in the case of investment rates, while no stationarity was noticed in the case of savings rate. This situation was different in emerging markets and developing economies. Namely, no stationarity was found in the savings rate of investment rate (Table 1).

The lack of stationarity in the time series mentioned above forced some modification of the functional form of the model in order to lead the non-stationary variables to 

stationarity. This modification means replacing the values of analysed variables with their first differences. It should also be stressed that due to the lack of cointegration between the variables in this model, there was no way to expand and transform this model into a vector error correction model. Thus, in order to estimate the relationship between the rates of investments and savings in advanced economies as well as in emerging markets and developing economies, a vector autoregression (VAR) model was used, as expressed by the set of equations below:

$$
\left(\frac{I}{G D P}\right)_{t}=\sum_{i=1}^{n} \alpha_{1}\left(\frac{I}{G D P}\right)_{t-i}+\sum_{i=1}^{n} \beta_{1}\left(\frac{S}{G D P}\right)_{t-i}+U_{1, t-i}
$$

$\left(\frac{S}{G D P}\right)_{t}=\sum_{i=1}^{n} \alpha_{2}\left(\frac{S}{G D P}\right)_{t-i}+\sum_{i=1}^{n} \beta_{2}\left(\frac{I}{G D P}\right)_{t-i}+U_{2, t-i}$

where: $i$ - the number of delays in the variables; other symbols are the same as formula (7).

Ultimately, the results of this parametric estimation for the VAR model are presented in the tables below (Tables 2 and 3).

Based on the data presented in Table 2, it can be observed that the savings retention coefficient in advanced economies is 0.57 with a significance level of $1 \%$. Thus, the calculated $\beta$ coefficient approximating 0.6 shows a relatively high international capital mobility in the analysed group of economies.

The influence of the flexibility of the rate of savings on the increase in the rate of investment in advanced economies. The coefficient was -0.72 with a significance level of $1 \%$, which showed a negative influence of investment changes in the saving sizes in the analysed countries.

Based on the data in Table 3, it can be observed that the savings retention coefficient in emerging markets and developing economies was approximately 0.22 between 1980 and 2010, with a reliability level of $10 \%$. Thus, the calculated $\beta$-coefficient showed a relatively higher international capital mobility in those countries, as compared to the developed ones.

On the other hand, the savings rate flexibility coefficient on the investment rate in emerging markets and developing economies was -0.09 , and thus statistically non-significant.

Subsequently, the influence of changes in the savings rate on those in the investment rate as well as the influence of changes in the investment rate on those in the savings rate were measured in developed, emerging markets and developing economies between 1980 and 2010. This was done using the so-called impulse response function, which is the function of the reaction of the investment and savings rates to an impulse in the form of a unit change of the savings and investment rates, respectively (Fig. 2).

Based on Figure 2, it was observed that a shock increase in the investment rate in advanced economies led to an immediate spike in the investment rate and its subsequent stabilisation over fourteen quarters from such a shock. On the other hand, a shock increase in the savings rate led to a gradual increase in the investment rate in the advanced economies over three subsequent quarters from such a shock, and its stabilisation over the next fourteen quarters. The reaction of the savings rate to a single shock change in the investment rate in advanced economies appeared different. Such a shock increase in the investment rate led to an immediate spike in savings rate and its subsequent stabilisation over fourteen quarters. Similar shock increases in the savings rate in advanced economies led to an immediate increase in savings rate and its subsequent stabilisation over fourteen quarters from such a shock.

When analysing the data shown in Figure 3, it was observed that a shock increase in the investment rate in emerging markets and developing economies led to an immediate increase in investment rate in the first quarter and its subsequent stabilisation over three quarters from such a shock. On the other hand, a shock increase in the savings rate led to a gradual increase in investment rates in the emerging markets and developing economies over two subsequent quarters from such a shock, and its stabilisation over the next four quarters. The reaction of the savings rate to a shock change in the investment rates in the emerging markets and developing economies appeared similar. A shock increase in the investment rate led to an immediate spike in savings rate within the first quarter and subsequent stabilisation over the next four quarters. On the other hand, a shock increase in the savings rate led to an immediate increase in the savings rate in emerging markets and developing economies, and its stabilisation over the next four quarters following the shock. 
Table 2. The results of estimating the VAR model for advanced economies.

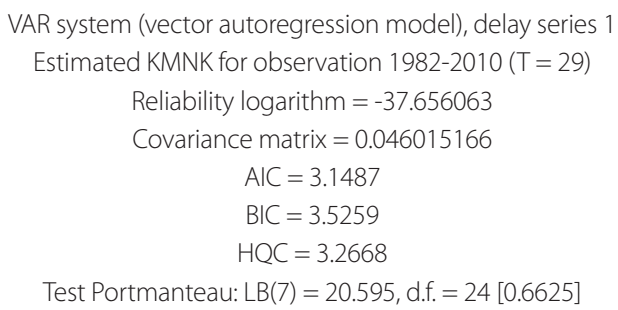

$\begin{array}{llllll}\text { Formula: I/GDP } & & & & \\ & \text { Coefficient } & \text { Standard error } & \text { t-Student } & \text { p-value } & \\ \text { const } & 17.0509 & 4.41015 & 3.8663 & 0.00070 & * * * \\ \text { I/GDP_1 } & 0.278994 & 0.185486 & 1.5041 & 0.14508 & \\ \text { d_S/GDP_1 } & 0.574485 & 0.199467 & 2.8801 & 0.00804 & * * * \\ \text { time } & -0.078608 & 0.0246926 & -3.1835 & 0.00387 & * * *\end{array}$

$\begin{array}{lcll}\text { Arithm.mean.of the dep.var. } & 21.72031 & \text { Stand.dev. of the dep.var. } & 1.394088 \\ \text { The sum of quad. residues } & 12.83008 & \text { Standard error of residues } & 0.716382 \\ \text { Determ. coeff., R-squared } & 0.764229 & \text { Corrected R-squared } & 0.735936 \\ \text { F(3,25) } & 27.01166 & \text { p-value for F-test } & 5.20 \mathrm{e}-08 \\ \text { Autocorrel. of residues - rho1 } & -0.067716 & \text { Durbin-Watson stat. } & 1.987185\end{array}$

Formula:d_S/GDP

\begin{tabular}{lccccc|} 
& Coefficient & Standard error & t-Student & p-value & \\
const & 17.0423 & 4.40686 & 3.8672 & 0.00070 & $* * *$ \\
I/GDP_1 & -0.718057 & 0.185347 & -3.8741 & 0.00068 & $* * *$ \\
d_S/GDP_1 & 0.467984 & 0.199318 & 2.3479 & 0.02710 & $*$ \\
time & -0.0812633 & 0.0246741 & -3.2935 & 0.00295 & $* * *$ \\
\hline
\end{tabular}

$\begin{array}{lcll}\text { Arithm.mean.of the dep.var. } & -0.156586 & \text { Stand.dev. of the dep.var. } & 0.860684 \\ \text { The sum of quad. residues } & 12.81093 & \text { Standard error of residues } & 0.715847 \\ \text { Determ. coeff., R-squared } & 0.382360 & \text { Corrected R-squared } & 0.308243 \\ F(3,25) & 5.158887 & \text { p-value for F-test } & 0.006502 \\ \text { Autocorrel. of residues - rho1 } & -0.079938 & \text { Durbin-Watson stat. } & 2.068826\end{array}$


Table 3. The results of estimated VAR model for the emerging markets and developing economies

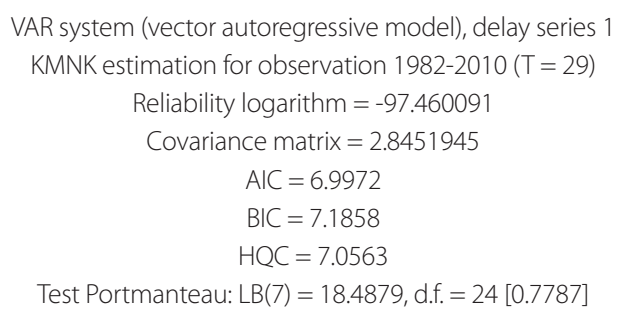

Formula: d_I/GDP

$\begin{array}{|lllll|} & \text { Coefficient } & \text { Standard error } & \text { t-Student } & \text { p-value } \\ \text { d_I/GDP_1 } & -0.181353 & 0.186299 & -0.9735 & 0.33897 \\ \text { d_S/GDP_1 } & 0.217897 & 0.108107 & 2.0156 & 0.05390\end{array}$

Arithm.mean.of the dep.var.

The sum of quad. residues

Determ. coeff., R-squared

$\mathrm{F}(2,27)$

Autocorrel. of residues - rho1

\subsection{1}

28.32592

0.136852

2.140417

$-0.025551$
Stand.dev. of the dep.var.

1.070808

Standard error of residues

1.024260

Corrected R-squared

0.104883

$p$-value for F-test

0.137137

Durbin-Watson stat.

\section{Formula:d_S/GDP}

$\begin{array}{lllll} & \text { Coefficient } & \text { Standard error } & \text { t-Student } & \text { p-value } \\ \text { d_l/GDP_1 } & -0.0953968 & 0.329771 & -0.2893 & 0.77458 \\ \text { d_S/GDP_1 } & 0.245269 & 0.191362 & 1.2817 & 0.21084\end{array}$

$\begin{array}{lcll}\text { Arithm.mean.of the dep.var. } & 0.235862 & \text { Stand.dev. of the dep.var. } & 1.818044 \\ \text { The sum of quad. residues } & 88.75465 & \text { Standard error of residues } & 1.813066 \\ \text { Determ. coeff., R-squared } & 0.057418 & \text { Corrected R-squared } & 0.022508 \\ \text { F(2, 27) } & 0.822363 & \text { p-value for F-test } & 0.450099 \\ \text { Autocorrel. of residues - rho1 } & -0.009470 & \text { Durbin-Watson stat. } & 1.883349\end{array}$


Figure 2. A graph of the impulse response function of investment and savings rates caused by a single change in savings and investment rates in advanced economies

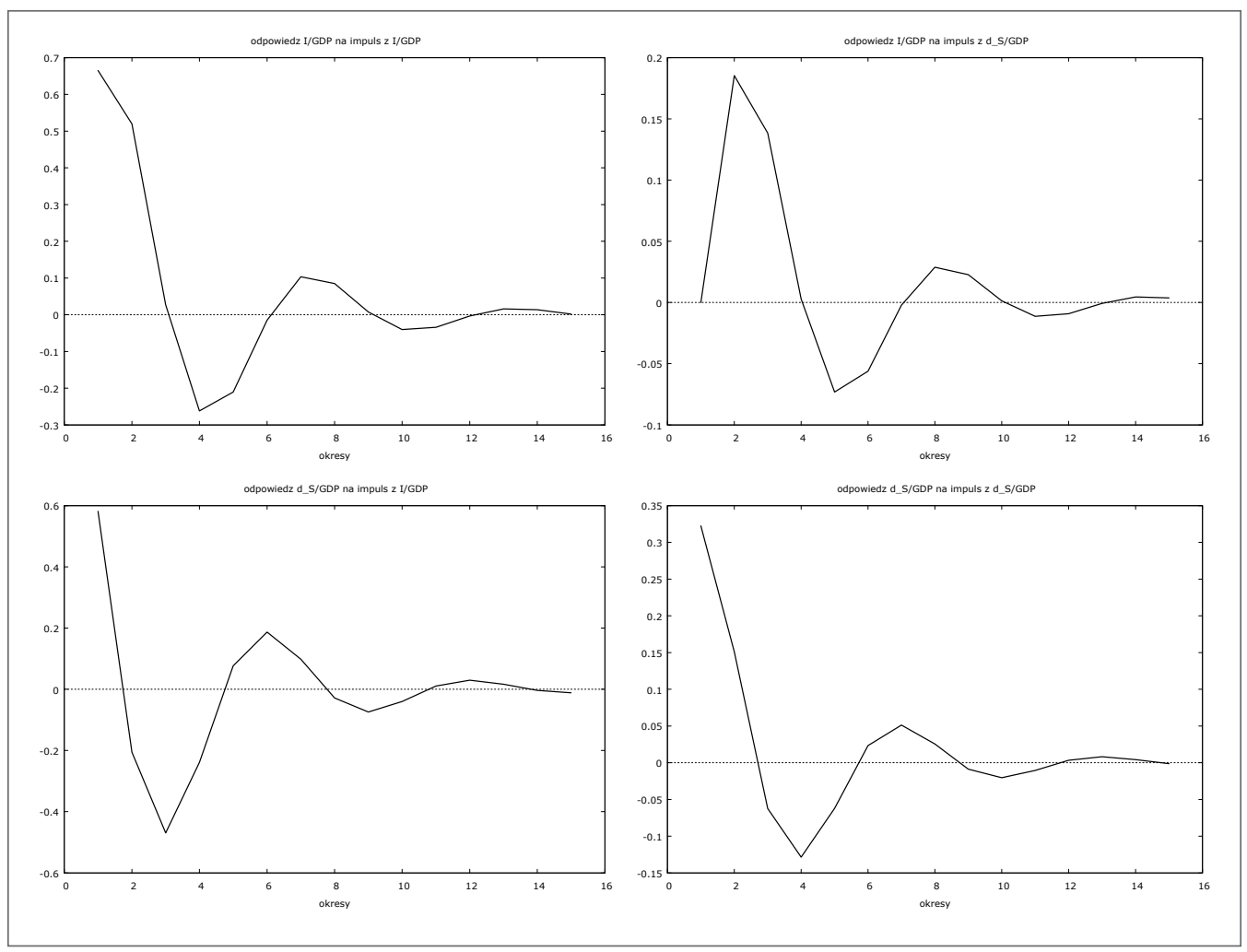

Source: Own study. 
Figure 3. Graphs of the impulse response function of the investment and savings rates caused by a single change in the savings and investment rates in emerging markets and developing economies

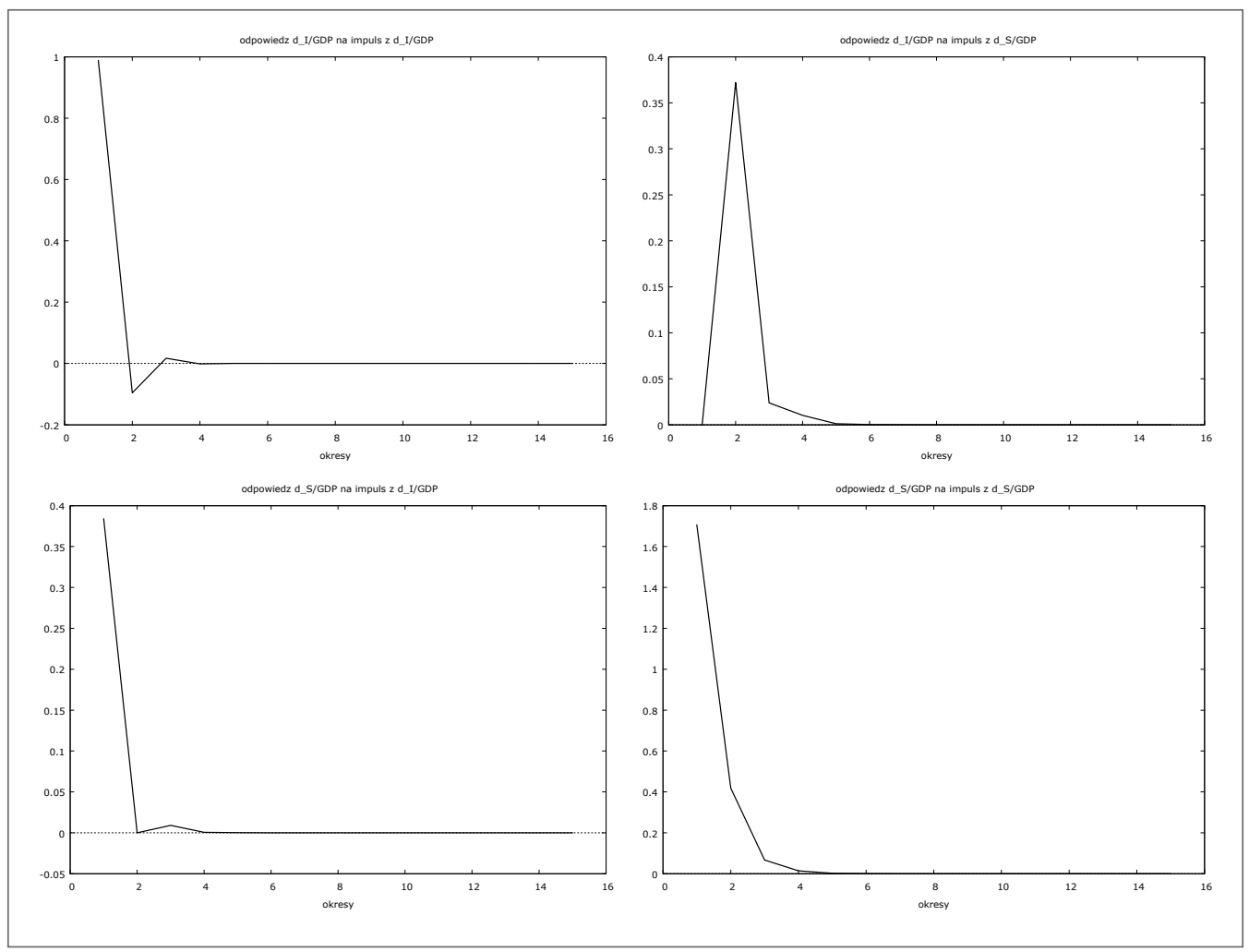

Source: Own calculations.

The next stage of the analysis involved the Cholesky Decomposition of the investment and savings rates in developed, emerging markets and developing economies in order to estimate the influence of the changes in the investments and savings rates on the changeability of these rates in the analysed countries (Table 4).

Based on the data presented in Table 4, it can be observed that the changes in the savings rate explained approximately $7 \%$ of the changeability in the investment rate in advanced economies. The inertia factor, i.e. the delayed changes in the investment rate was the most significant factor in explaining the changeability of the investment rate in advanced economies. On the other hand, the changes in the investment rate explained approximately $82 \%$ of the variability of the savings rate in advanced economies, and the inertia factor (delayed changes in the investment rate) had the smallest influence.
Based on the data in Table 5, it can be observed that changes in the savings rate explained approximately $12 \%$ of the variability in the investment rate in emerging markets and developing economies. The inertia factor, i.e. the delayed changes in the investment rate was the most significant factor in explaining the changeability of the investment rate in advanced economies. On the other hand, the changes in the investment rate explained approximately $5 \%$ of the variability in savings rate in emerging markets and developing economies, while the inertia factor had the largest influence on explaining the variability in savings rate in these countries.

Based on this analysis, it can be observed that the strongest Feldstein-Horiok effect could be seen between 1980 and 2010 in advanced economies, while a noticeably weaker Feldstein-Horiok effect was present in emerging markets and developing economies. Thus, 

the results of this research coincide with the analyses from Murthy (2007), Vamvakidis \& Wacziarg (1998), Samba (2010), and others, who have shown a relatively low savings retention rate in developing economies, between 0.18 and 0.29 . This relatively low savings retention in emerging markets and developing economies points to high international capital mobility in these countries. Such a relatively high international capital mobility in emerging markets and developing economies is caused by progressive deregulation of capital markets, integration of local financial markets with the global market, as well as by the technological revolution in these economies. The relatively high capital mobility in emerging markets and developing economies has serious consequences for the effectiveness of fiscal and monetary policies, the stability of currency exchange rates, international cooperation of monetary institutions as well as for the independence of central banks in these countries. On the other hand, this high international capital mobility creates opportunities to acquire foreign savings to finance domestic investments, which may accelerate the economic development. Moreover, international capital mobility makes it easier to limit the burden taxation and external effects on relatively immobile domestic factors of production, such as workforce (Obstfeld, Shambaugh, Taylor 2004; Chung, Davig, Leeper 2007)

It should also be stressed that the involvement of a growing number of countries, especially emerging ones, in regional economic integration contributes to the increasing tendency among domestic entities to invest in foreign assets (a decline in home bias), which results in a drop in savings retention in these countries (Ahearne, Griever \& Warnock, 2004).

There is no unanimity among economists as to why the Feldstein-Horiok effect is present and strong, especially in advanced economies. Most authors suggest that the existence of strong Feldstein-Horiok effect does not contradict capital mobility. There is a popular belief today that this effect may be caused by external factors (international shock) as well as by influence savings and investments at the same time. Such shocks may involve changes in the effectiveness of the factors of production or changes in the demographic structure. Some economists also argue that such results may be influenced by the governmental policies aimed at stabilising current accounts. Moreover, a relatively strong relationship between investments and savings may be caused by the fact that the international capital mobility depends on the size of enterprises operating in a given economy (large corporations and the public sector have a better access to the international markets), and can stem from an economic structure, which stimulates high investments and savings at the same time (Liberda, 1999).

\section{Conclusions}

A general conclusion from the above analysis shows that the international capital mobility has to be analysed in the categories of the extent of its mobility, and perfect capital mobility should not be assumed. The results suggest the presence of international capital mobility in all analysed countries, while an autarkic economy was not found in any case. The savings retention coefficient calculated based on the VAR model was at 0.57 in advanced economies and at 0.22 in emerging markets and developing economies. Thus, it has been proven that international capital mobility is relatively stronger in less developed economies and relatively weaker in more developed ones.

Obstfeld (1986) claims, however, that a lower savings retention coefficient in developing economies is caused not by higher international capital mobility, but by the fact, that these countries have weaker ability to retain long-term stability of their capital accounts. Moreover, he claims that the global interest rate is not exogenous, as Feldstein-Horioka hypothesis assumes, and that it influences both domestic savings and investments. That is why a drop in domestic savings leads to an increase in global interest rate, which can cause an outflow of capital and a decrease in domestic investments.

According to the results, even though the integration of international financial markets are still growing, they are also largely segmented, which means that domestic savings are - to a large extent - invested in their country of origin. However, according to Feldstein (1994), this situation applies mainly to portfolio investments, which are sensitive to fluctuation in productivity and, consequently, in both domestic and foreign interest rates.

A relatively high relationship between investments and savings in advanced economies and in relatively high international capital mobility also means a sig- 
nificant and positive relationship between the changes in the budget deficit and the current account deficit of these countries. The results may, therefore, suggest, that an economic policy aimed at retaining the internal balance plays a significant role in limiting the imbalance of the current account in case of advanced economies, while a policy aimed at regaining the external balance plays a role in also regaining the internal balance in such countries (Misztal, 2011).

These results may also serve as a starting point for subsequent analyses of the relationship between international capital mobility and the economic development of various countries.

\section{References}

1. Ahearne, A.G., Griever, W.L., \& Warnock, F. E. (2004). Information costs and home bias: An analysis of U.S. holdings of foreign equities. Journal of International Economics, 62(2), 313-336.

2. Apergis, N. \& Tsoulfidis, L. (1997) The relationship between saving and finance: theory and evidence from EU countries. Research in Economics, 51(4), 333-358.

3. Argimon, I. \& Roldan, J.M. (1994). Saving, investment and international capital mobility in EC countries. European Economic Review, 38(1), 59-67.

4. Baxter, M. \& Crucini, M.J. (1993). Explaining Saving-Investment Correlations. American Economic Review, 83(3), 416-36.

5. Bhaskara B.R., Tamazian, A. \& Kumar S. (2010). Systems GMM Estimates of the Feldstein-Horioka Puzzle for the OECD Countries and Tests for Structural Breaks. Economic Modelling, 27(5), 1269-1273.

6. Caporale, M. G., Panopoulou, E. \& Pittis, N. (2005). The Feldstein Horioka puzzle revisited: A Monte Carlo study. Journal of International Money and Finance, 24(7), 1143-1149.

7. Christopoulos, D. K. (2007). A reassessment of the Feldstein-Horioka hypothesis of perfect capital mobility: evidence from historical data. Empirica, 34(3), 273-280.

8. Chung H. T., Davig T. \& Leeper E. (2007). Monetary and fiscal policy switching. Journal of Money, Credit and Banking, 39(4), 809-842.

9. Deckle, R. (1996). Saving-investment associations and capital mobility: On the evidence from Japa- nese regional data. Journal of International Economics, 41(1-2), 53-72.

10. Center for Social and Economic Research. (1999). Determinants of Saving in Poland, B. Liberda, (Ed.), Warsaw.

11. Di Iorio, F. \& Fachin, S. (2007). Testing for breaks in cointegrated panels - with an application to the Feldstein-Horioka puzzle. Economics - The OpenAccess, Open-Assessment E-Journal, 1(14), 1-23.

12. Feldstein, M. \& Horioka, C. (1980). Domestic saving and international capital flows. Economic Journal, 90(358), 314-329.

13. Fidrmuc, J. (2003). The Feldstein-Horioka puzzle and twin deficits in selected countries, Economics of Planning, 36(2), 135-152.

14. Francesca, D. \& Stefano, F. (2010). Savings and investments in the OECD, 1970-2007: A panel cointegration test with breaks. Munich Personal RePEc Archive Paper, 26781.

15. Jansen, J. (1996). Estimating savings-investments correlations: Evidence from OECD countries based on an error correction model. Journal of International Money and Finance, 15(5), 749-781.

16. Ketenci, N. (2010). The Feldstein Horioka puzzle by groups of OECD members: the panel approach. Munich Personal RePEc Archive Paper, 5848.

17. Marinheiro C. F. (2008). Ricardian equivalence, twin deficits, and the Feldstein-Horioka puzzle in Egypt. Journal of Policy Modeling, 30(6), 10411056.

18. Mastroyiannis, A. (2007). Current account dynamics and the Feldstein and Horioka puzzle: The case of Greece. The European Journal of Comparative Economics, 4(1), 91-99.

19. Miller, S. M. (1988). Are saving and investment cointegrated?, Economics Letters, 27(1), 31-34.

20. Misztal, P. (2011). The interrelations between budget deficit and current account deficit in Poland between 1999 and 2009. Ekonomista, 2, 183-203.

21. Mukhtar, T., Zakaria, M. \& Ahmed, M. (2007). An empirical investigation for the twin deficits hypothesis in Pakistan. Journal of Economic Cooperation, 28(4) 63-80.

22. Murthy, N.R.V. (2007). Feldstein Horioka puzzle in Latin American and Caribbean countries: Evidence from likelihood-based cointegration tests in heterogeneous panels. International Research 
Journal of Finance and Economics, 11, 112-122.

23. Obstfeld, M. \& Rogoff, K. (2011). Perspectives on OECD economic integration: Implications for U.S. current account adjustment. UC Berkeley: Center for International and Development Economics Research, 2000, http://escholarship.org.

24. Obstfeld M., Shambaugh, J. C. Taylor A. M. (2004). The Trilemma in History: Trade-offs Among Exchange Rates, Monetary Policies and Capital Mobility. CEPR Discussion Papers, No. 4352.

25. Onafowara, O. A., Owoye, O. \& Huart F. (2011). The temporal relationship between saving and investment: Evidence from advanced EU countries. International Journal of Business and Social Science, 2(2), 1-12.

26. Rao, B. B., Tamazian, A. \& Kumar S. (2009). Systems GMM estimates of the Feldstein-Horioka puzzle for the OECD countries and tests for structural breaks. Munich Personal RePEc Archive Paper, 15312.

27. Samba, M. C. (2010). Saving-investment correlation and capital mobility in Sub-Saharan African countries: A reappraisal through inward and outward capital flows' correlation. International Journal of Economics and Finance, 2(2), 97-106.

28. Sinn, S. (1992). Saving-investment correlations and capital mobility: On the evidence from annual data. Economic Journal, 102(414), 1162-1170.

29. Strzała, K. (2005). The Correlation and Investment and Saving in European Union Countries - Empirical Verification Using Panel Approach. The Works and Materials of the Faculty of Management, University of Gdańsk - econometric models and forecasts for economic development, 1, 141-157.

30. Tsoukis, C. \& Alyousha, A. (2002) The FeldsteinHorioka puzzle, saving-investment causality and international financial market integration. Journal of Economic Integration, 16(2), 262-277.

31. Vamvakidis, A. \& Wacziarg R. (1998). Developing Economies and the Feldstein-Horioka Puzzle. International Monetary Fund Working Paper, 98(2).

32. World Economic Outlook, International Monetary Fund, Washington, 2010, October, http:// www.imf.org.

\section{Notes}

1. In studies by the World Bank and the International Monetary Fund, the group of economically developed countries are called advanced economies. The developing countries are called developing economies and, since 2004, they are known as emerging markets and developing economies. The first group (advanced economies) includes 34 economies, and the second group (emerging markets and developing economies) includes 150 countries. 
